University of Thi-Qar Journal Vol.10 No.3 SEP 2015

Web Site: https://jutq.utq.edu.iq/index.php/main Email: journal@jutq.utq.edu.iq

\title{
F-CONTINUOUS FUNCTIONS AND SUB-F-CONTINUOUS
} FUNCTIONS

https://doi.org/10.32792/utq/utj/vol10/3/10

Mayada Gassab Mohammed

Department of Mathematics

College of Education

University of Thi-Qar

\begin{abstract}
:
In this paper we introduce and study F-closed sets and new types of generalized continuity.
\end{abstract}

\section{Introduction:}

A subset A of a topological space $\mathrm{X}$ is said to be F-closed if it is the intersection of an open and closed set . in this paper we introduce three different notions of generalized continuity, namely F- irresoluteness , F-continuity and sub-F- continuity and we discuss some properties of these functions

\section{Definition (1-1):}

A subset $A$ of a space $(X, \tau)$ is called F-closed if $A=U \cap V$ such that $U$ is open set and $\mathrm{V}$ is closed set in $\mathrm{X}$. we denote the collection of all F-closed subsets of $\mathrm{X}$ by $\mathrm{F}(\mathrm{X}, \tau)$.

\section{$\operatorname{Remarks}(1-2)$ :}

A subset $\mathrm{A}$ of $\mathrm{X}$ is F-closed set iff $\mathrm{X}-\mathrm{A}$ is the union of an open set and a closed set .

1. Any open (resp. closed) subset of $\mathrm{X}$ is F-closed set.

2. The complement of a F-closed subset need not be F-closed set .

\section{Definition (1-3) :}

A subset $A$ of a space $(X, \tau)$ is said to be preopen set if $A \subseteq \operatorname{int}(\mathrm{cl} A)$.

\section{Remarks (1-4) :}

1. Every open set is preopen set .

2. Every preopen and F-closed set is open set . 
University of Thi-Qar Journal Vol.10 No.3 SEP 2015

Web Site: https://jutq.utq.edu.iq/index.php/main Email: journal@jutq.utq.edu.iq

\section{Proposition (1-5):}

Let $\mathrm{A}$ be a subset of a space $(\mathrm{X}, \tau)$, then the following statements are equivalent:

1. A is F-closed set .

2. $\mathrm{A}=\mathrm{U} \cap \mathrm{cl} \mathrm{A}, \mathrm{U}$ is open set in $\mathrm{X}$.

3. $\mathrm{cl} \mathrm{A-A}$ is closed set .

\section{Remark (1-6) :}

Let $A$ any sub set of a space $(X, \tau)$ then $A$ need not be F-closed set, but if $(X, \tau)$ has property which every dense subset of $\mathrm{X}$ is open set then A is F-closed set .

\section{Proposition (1-7) :}

Let $\mathrm{A}$ and $\mathrm{B}$ be F-closed subsets of a space $(\mathrm{X}, \tau)$. If $\mathrm{A} \cap \operatorname{clB}=\mathrm{clA} \cap \mathrm{B}=\phi$, then $\mathrm{A} \cup \mathrm{B} \in \mathrm{F}(\mathrm{x}, \tau)$.

\section{Proof :}

Suppose there are open sets $\mathrm{U}$ and $\mathrm{V}$ such that $\mathrm{A}=\mathrm{U} \cap \mathrm{cl} \mathrm{A}$ and $\mathrm{B}=\mathrm{V} \cap \mathrm{clB}$.

Since $\mathrm{A} \cap \mathrm{clB}=\mathrm{B} \cap \mathrm{cl} \mathrm{A}=\phi$, then $\mathrm{A} \cup \mathrm{B}=(\mathrm{U} \cup \mathrm{V}) \cap \mathrm{cl}(\mathrm{A} \cup \mathrm{B})$, from definition of $\mathrm{F}$-closed set we obtain $\mathrm{A} \cup \mathrm{B} \in \mathrm{F}(\mathrm{X}, \tau)$.

\section{Definition (1-8) :}

A function $\mathrm{f}:(\mathrm{X}, \tau) \rightarrow\left(\mathrm{Y}, \tau^{\prime}\right)$ is said to be F-irresolute function iff for any F-closed set $\mathrm{U}$ in $\mathrm{Y}$ then $\mathrm{f}^{-1}(\mathrm{U})$ is F-closed set in $\mathrm{X}$.

\section{Definition (1-9) :}

A function $\mathrm{f}:(\mathrm{X}, \tau) \rightarrow\left(\mathrm{Y}, \tau^{\prime}\right)$ is said to be F-continuous function iff for any open set $\mathrm{U}$ in $\mathrm{Y}$ then $\mathrm{f}^{-1}(\mathrm{U})$ is F-closed set in $\mathrm{X}$.

\section{Definition (1-10) :}

A function $(\mathrm{X}, \tau) \rightarrow\left(\mathrm{Y}, \tau^{\prime}\right)$ is said to be sub-F-continuous function if there is a subbase or base $\mathrm{B}$ for $\mathrm{Y}$ such that for any $\mathrm{U} \in \mathrm{B}$ then $\mathrm{f}^{-1}(\mathrm{U})$ is F-closed set in $\mathrm{X}$. 
University of Thi-Qar Journal Vol.10 No.3 SEP 2015

Web Site: https://jutq.utq.edu.iq/index.php/main Email: journal@jutq.utq.edu.iq

\section{Theorem (1-11) :}

Let $\mathrm{f}:(\mathrm{X}, \tau) \rightarrow\left(\mathrm{Y}, \tau^{\prime}\right)$ be a function, then

1. If $\mathrm{f}$ is continuous function then $\mathrm{f}$ is F-irresolute function.

2. If $\mathrm{f}$ is F-irresolute function then $\mathrm{f}$ is F-continuous function .

3. If $\mathrm{f}$ is F-continuous function then $\mathrm{f}$ is sub-F- continuous function .

\section{Remark (1-12) :}

The converse of theorem above is not true in general. The following examples explain that.

\section{Example (1-13) :}

Let $\mathrm{f}:\left(\mathrm{R}, \tau_{\mathrm{u}}\right) \rightarrow\left(\mathrm{R}, \tau_{\mathrm{u}}\right), \tau_{\mathrm{u}}$ is usual topology on $\mathrm{R}$, we will define $\mathrm{f}$ on $\mathrm{R}$ as follows $: f(x)=1$ if $x>0$ and $f(x)=x$ if $x \leq 0$

We note that $\mathrm{f}$ is not continuous function but $\mathrm{f}$ is F-irresolute function because for any F-closed set $\mathrm{U}$ in $\mathrm{R}$ then $\mathrm{f}^{-1}(\mathrm{U})=\mathrm{U} \cup(0, \infty)$ if $1 \in \mathrm{U}$ and

$\mathrm{f}^{-1}(\mathrm{U})=\mathrm{U} \cap(-\infty, 0)$ if $1 \notin \mathrm{U}, \mathrm{U} \cup(0, \infty)$ and $\mathrm{U} \cap(-\infty, 0)$ are F-closed sets ,therefore, $\mathrm{f}$ is F-irresolute function .

\section{Example (1-14) :}

Let $\mathrm{f}:\left(\mathrm{R}, \tau_{\mathrm{u}}\right) \rightarrow\left(\mathrm{R}, \tau_{\mathrm{u}}\right)$ such that $\mathrm{f}(\mathrm{x})=\mathrm{x}$ if $\mathrm{x} \neq 0$ and $\mathrm{f}(0)=1$. For any $\mathrm{U} \subset \mathrm{R}$ we have $\mathrm{f}^{-1}(\mathrm{U})=\mathrm{U}-\{0\}$ if $1 \notin \mathrm{U}$ and $\mathrm{f}^{-1}(\mathrm{U})=\mathrm{U} \cup\{0\}$ if $1 \in \mathrm{U}$.

Hence, if $U$ is an open interval then $f^{-1}(U)$ is F-closed . thus $f$ is sub-F-continuous function, but $\mathrm{f}$ is not F-continuous function because there is an open set $\mathrm{U}=\mathrm{R}-\{0\} \cup\{1 \backslash \mathrm{n} \mid \mathrm{n} \in \mathrm{N}, \mathrm{n} \geq 2\}$ and $\mathrm{f}^{-1}(\mathrm{U})=\{\mathrm{x} \in \mathrm{R} \mid \mathrm{x} \neq 1 \backslash \mathrm{n}$ for each $\mathrm{n} \geq 2\}$ is not Fclosed set .

\section{Example(1-15) :}


University of Thi-Qar Journal Vol.10 No.3 SEP 2015

Web Site: https://jutq.utq.edu.iq/index.php/main Email: journal@jutq.utq.edu.iq

Let $\mathrm{E}=\{1 \backslash \mathrm{n}, \mathrm{n} \in \mathrm{N}\}$, let $\mathrm{f}:\left(\mathrm{R}, \tau_{\mathrm{u}}\right) \rightarrow\left(\mathrm{R}, \tau_{\mathrm{u}}\right)$ such that $\mathrm{f}(\mathrm{x})=\mathrm{x} \quad$ if $\mathrm{x} \in \mathrm{E}$ and $f(x)=0$ if $x \in R-E$, $f$ is not F-irresolute function because $\{0\}$ is F-closed set in $R$ but $f^{-}$ ${ }^{1}(0)=\mathrm{R}-\mathrm{E}$ is not $\mathrm{F}$ - closed in $\mathrm{R}$

We note that $f$ is F-continuous function because any an open set $U$ then $\mathrm{f}^{-1}(\mathrm{U})$ is F-closed set in $\mathrm{R}$.

\section{Remark (1-16) :}

From theorem (1-11), we get the relation among F-irresolute ,F-continuous, sub-Fcontinuous and continuous function as follows

Continuous function $\rightarrow$ F-irresolute function $\rightarrow$ F- continuous function $\rightarrow$ sub-Fcontinuous function.

\section{Defintion (1-17) :}

A function $\mathrm{f}:(\mathrm{X}, \tau) \rightarrow\left(\mathrm{Y}, \tau^{\prime}\right)$ is said to be pre-continuous function iff for any an open set $U$ in $Y$ then $f^{-1}(U)$ is preopen set in $X$.

\section{Theorem (1-18) :}

A function $f:(X, \tau) \rightarrow\left(Y, \tau^{\prime}\right)$ is continuous function iff $f$ is pre-continuous and sub-Fcontinuous function .

\section{Proof :}

Suppose that $\mathrm{f}$ is pre-continuous and sub-F-continuous function and $\mathrm{B}$ is a base for $\mathrm{Y}$ such that for any $\mathrm{U} \in \mathrm{B}$ then $\mathrm{f}^{-1}(\mathrm{U})$ is F-closed set. Now let $\mathrm{V} \in \tau^{\prime}$ and $\mathrm{f}(\mathrm{x}) \in \mathrm{V}$.

There is $\mathrm{a} \in \mathrm{U} \in \mathrm{B}$ such that $\mathrm{f}(\mathrm{x}) \in \mathrm{U} \subseteq \mathrm{V}$.

Since $\mathrm{f}^{-1}(\mathrm{U})$ is pre-open and F-closed set then $\mathrm{f}^{-1}(\mathrm{U})$ is an open set, therefore, $\mathrm{f}$ is continuous function .

\section{Proposition (1-19) :}

Let $\mathrm{f}:(\mathrm{X}, \tau) \rightarrow\left(\mathrm{Y}, \tau^{\prime}\right)$ and $\mathrm{g}:\left(\mathrm{Y}, \tau^{\prime}\right) \rightarrow\left(\mathrm{Z}, \tau^{\prime \prime}\right)$ two functions, then

1. If $\mathrm{f}$ and $\mathrm{g}$ are F-irresolute functions, then gof is F-irresolute function.

2. If $\mathrm{f}$ is F-continuous function and $\mathrm{g}$ is continuous functions, then gof is Fcontinuous function .

Remarks (1-20) : 
University of Thi-Qar Journal Vol.10 No.3 SEP 2015

Web Site: https://jutq.utq.edu.iq/index.php/main Email: journal@jutq.utq.edu.iq

1. The composition of two F-continuous functions need not be F-continuous function .

2. The composition of a sub- F-continuous function and continuous function need not be sub-F-continuous function .

\section{References:}

[1] Samir B. Hadid ,Introduction to general topology .Mussel, 1988.

[2] G .B . Navalagi, Definition bank in general topology , 16/7/2000.

[3] Ganster, M . and Reilly ,A decomposition of continuity, New York , 1977.

[4]Wilhelm , M . Some negative examples concerning nearly continuity, comment . Math. 28 (1986), 187-194 . 